\title{
Effect of ribavirin on hepatitis A virus replication in vitro
}

\author{
RABINDRA K ChAUDhARY, PHD, DIP, BACT, ANTON P ANDONOV, MD, PHD
}

\begin{abstract}
RK CHAUdhaRY, AP ANDonov. Effect of ribavirin on hepatitis A virus replication in vitro. Can J Infect Dis 1992;3(2):67-70. The effect of ribavirin on fetal Rhesus monkey kidney cells (FRhK-4) acutely or chronically infected with hepatitis A virus was studied. The effect of ribavirin on hepatitis A virus yield as detected by radioimmunoassay in acutely infected FRhK-4 cells was dependent on hepatitis A virus inoculum dose. Treatment with $100 \mu \mathrm{g} / \mathrm{mL}$ ribavirin completely inhibited hepatitis A virus growth in cultures infected with 100 to 800 tissue culture infectious dose 50 (TCID50) hepatitis A virus, but inocula of 800 to 1600 TCID 50 resulted in limited production of virus. The effect was time dependent and required more than $96 \mathrm{~h}$ of treatment to inhibit the virus completely. Ribavirin was less effective in treating cells persistently infected with hepatitis A virus, although there was significant inhibition of hepatitis A virus $(82 \%)$ in persistently infected cells as well. Ribavirin had some inhibitory effect on cell growth; treatment with 25,50 or $100 \mu \mathrm{g} / \mathrm{mL}$ ribavirin reduced cell growth by approximately 0,20 and $40 \%$, respectively.
\end{abstract}

Key Words: Hepatitis A, Radioimmunoassay, Ribavirin

\begin{abstract}
Activité de la ribavirine sur la réplication du virus de l'hépatite $A$ in vitro
RESUME: Les auteurs ont étudié l'activité de la ribavirine contre le virus de l'hépatite A (VHA) se multipliant sur des cultures de cellules rénales de foetus de singe Rhésus (FRhK-4) infectées de façon aiguë ou chronique. Mesurée par radio-immunodosage, l'activité de la ribavirine sur le rendement du VHA à l'intérieur des cellules FRhK-4 variait en fonction de la dose de l'inoculum. Administrée à la posologie de $100 \mu \mathrm{g} / \mathrm{mL}$, la ribavirine inhibait complètement la réplication virale dans les cultures infectées par une TCID50 de 100 à 800 mais les inocula à la dose de 800 à 1600 TCID50 ont résulté en une réplication limitée du virus. L'activité variait en fonction du facteur temps et l'inhibition totale du virus requérait un traitement de plus de 96 heures. Quoique donnant des résultats appréciables (82\%), la ribavirine était moins efficace dans le traitement des cellules infectées de façon persistante par le VHA. La ribavirine exerçait une certaine action inhibitrice sur la prolifération cellulaire, le traitement par 25, 50 ou $100 \mu \mathrm{g}$ de ribavirine par $\mathrm{mL}$ ayant produit une réduction de 0,20 et $40 \%$, respectivement.
\end{abstract}

Laboratory for Viral Hepatitis, National Laboratory for Special Pathogens, Bureau of Microbiology, Laboratory Centre for Disease Control, Health and Welfare Canada, Ottawa, Ontario

Correspondence and reprints: Dr RK Chaudhary, Head, Laboratory for Viral Hepatitis, Bureau of Microbiology, Virus Laboratory Building \#10, LCDC, Tunney's Pasture, Ottawa, Ontario K1A OL2. Telephone (613) 957-0180

Received for publication February 5, 1991. Accepted April 25, 1991 
T HE CHANGING EPIDEMIOLOGY OF HEPATITIS A INFECTION in Western countries has resulted in a lack of naturally acquired immunity in many adults. Infection with hepatitis A virus is becoming known as the traveller's disease' and is associated with considerable morbidity $(1,2)$. The occurrence of more clinically severe forms of the illness stresses the need for an effective antiviral treatment. Recently, ribavirin, which has already found clinical application in treatment of respiratory syncytial virus infection (3), was reported to reduce hepatitis $\mathrm{A}$ virus growth in tissue culture $(2,4)$. The effect of ribavirin on chronically infected cells has not been reported. In this report the authors describe the inhibitory effect of ribavirin on replication of hepatitis A virus in acutely or chronically infected fetal Rhesus monkey kidney cells (FRhK-4).

\section{MATERIALS AND METHODS}

A continuous cell line (FRhK-4) was obtained from the American Type Culture Collection. The cells were grown in minimum essential medium (Gibco) containing $10 \%$ fetal calf serum at $37^{\circ} \mathrm{C}$. The FRhK-4 cells persistently infected with hepatitis A virus were maintained in the same manner as normal cultures. Cells persistently infected with hepatitis A virus were developed by serial passage and were used for ribavirin treatment at the 40th passage. Viable cell counts were determined by the trypan-blue exclusion test.

Hepatitis A virus was isolated from a stool sample of a Chinese patient (from the People's Republic of China) in FRhK-4 cells. Infectivity was titrated in FRhK-4 cells and TCID $50 / \mathrm{mL}$ was calculated by the Kârber method (5).

Ribavirin (1-beta-D-ribofuranosyl-1,2,4-triazole-3carboxamide) was purchased under the trade name Virazole from ICN Canada Ltd. Different concentrations of ribavirin were prepared in minimum essential medium containing 3\% or $10 \%$ fetal calf serum as required.

A modified Havab-M radioimmunoassay (6) was used for the detection of hepatitis A virus antigen harvested from infected cell cultures. A ratio of sample to negative control mean ( $\mathrm{S} / \mathrm{N}$ ratio) of at least 2.1 was considered positive.

Freshly seeded or confluent monolayers of FRhK-4 cells in $25 \mathrm{~cm}^{2}$ flasks were treated with different concentrations of ribavirin $(25,50$ and $100 \mu \mathrm{g} / \mathrm{mL})$, and untreated cells were kept as control. The flasks were incubated at $37^{\circ} \mathrm{C}$ for seven days and observed microscopically for visible cytotoxic effects. At the end of the incubation period the monolayers were trypsinized and viable cells counted. Relative growth was expressed as the ratio of the number of viable cells in ribavirintreated versus control cultures.

FRhK-4 cells (in $25 \mathrm{~cm}^{2}$ flasks) were inoculated with $100,200,400,800$ or 1600 tissue culture infectious dose 50 (TCID 50$) / \mathrm{mL}$ of hepatitis A virus in $0.1 \mathrm{~mL}$ and adsorbed for $4 \mathrm{~h}$ at $37^{\circ} \mathrm{C}$. The monolayers were washed and maintained in medium containing different con-

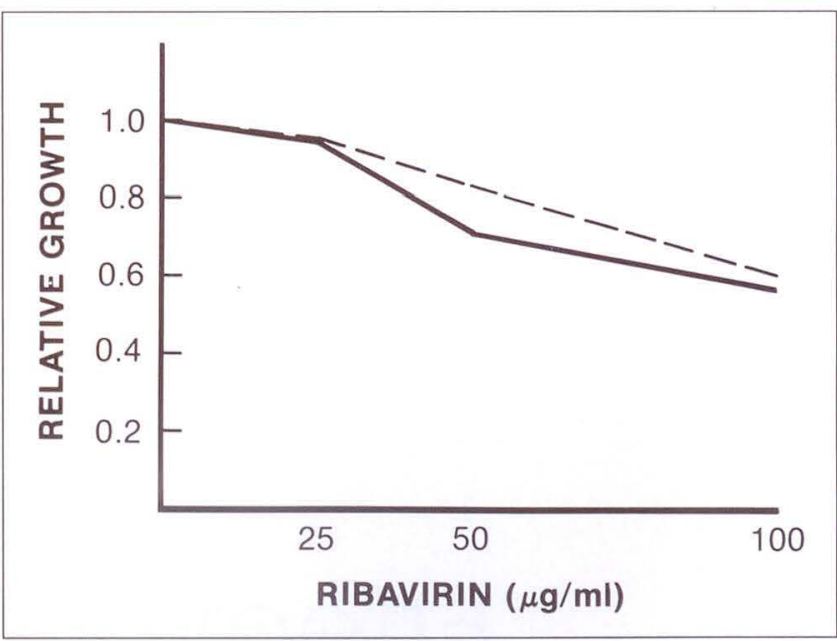

Figure 1) Effect of ribavirin on cell growth. The cells were treated when a monolayer was formed (-) or at the time of splitting (- - ). The cells were counted and relative growth was calculated by dividing the number of cells from the ribavirin-treated bottle by number of cells from the untreated bottles

centrations of ribavirin $(0,50$ or $100 \mu \mathrm{g} / \mathrm{mL})$. All flasks were incubated for seven days at $37^{\circ} \mathrm{C}$, and then cells were harvested by three cycles of freezing and thawing in $0.4 \mathrm{~mL}$ phosphate-buffered saline containing $0.1 \%$ nonionic detergent 40. Preparations were centrifuged and supernatants tested for the presence of hepatitis A virus antigen by radioimmunoassay.

The effect of short term treatment with ribavirin on hepatitis A virus was determined by inoculating cells with 100 TCID 50 of virus and then exposing them to 100 $\mu \mathrm{g} / \mathrm{mL}$ of ribavirin for $0,48,72$ and $96 \mathrm{~h}$. At the end of treatment the ribavirin was replaced by minimum essential medium containing 3\% fetal calf serum and the cells were further incubated for seven days. Cells were harvested and tested for hepatitis A virus. All experiments were done in triplicate.

Two sets of flasks $\left(25 \mathrm{~cm}^{2}\right)$ with a complete monolayer of chronically infected FRhK-4 were treated with each dosage of ribavirin $(0,25,50$ or $100 \mu \mathrm{g} / \mathrm{mL})$ and incubated for seven days. One set was then harvested as in the case of acute infection, while the second set was trypsinized and subcultured. When new monolayers were formed, they were treated again with the same doses of ribavirin. The presence of hepatitis A virus antigen in treated and control cells was determined by radioimmunoassay as above.

\section{RESULTS}

The results in terms of relative growth are illustrated in Figure 1. The doses of ribavirin used caused only minor morphological changes in FRhK-4 cells. Some rounded cells were detected in cultures treated with $100 \mu \mathrm{g} / \mathrm{mL}$ ribavirin. Morphological changes were not observed in cultures treated with 25 or $50 \mu \mathrm{g} / \mathrm{mL}$. 
Treatment with ribavirin at $100 \mu \mathrm{g} / \mathrm{mL}$ at the time of seeding and when the monolayer had formed resulted in relative growth of 61 and 57\%, respectively. Relative growth under the two treatment regimens was 84 and $71 \%$ when doses of $50 \mu \mathrm{g} / \mathrm{mL}$ were used. The growth rate was not affected by treatment with $25 \mu \mathrm{g} / \mathrm{mL}$.

The effect of ribavirin on the expression of hepatitis A virus antigen in acutely infected cells is shown in Figure 2. Cultures inoculated with 100, 200 or 400 TCID50 and treated with $50 \mu \mathrm{g} / \mathrm{mL}$ ribavirin produced $\mathrm{S} / \mathrm{N}$ ratios $6.1,7.3$ and 12.7 , respectively, ie, significantly less than the yields from drug-free hepatitis A virus control cultures (S/N ratios 41 to 47). Treatment of cells with $100 \mu \mathrm{g} / \mathrm{mL}$ ribavirin completely inhibited the expression of hepatitis A virus antigen in cultures inoculated with 100 to 800 TCID50. When the cultures were inoculated with 1600 TCID50 a small amount of residual hepatitis A virus antigen remained detectable by radioimmunoassay. The hepatitis A virus yield from untreated cells inoculated with 800 or 1600 TCID50 is not shown in the figure.

The inhibition of hepatitis A virus by ribavirin was time dependent. The shortest period of treatment (48 h) with $100 \mu \mathrm{g} / \mathrm{mL}$ of ribavirin inhibited the expression of hepatitis A virus antigen by $83.2 \%$, whereas with the longest period of treatment $(96 \mathrm{~h})$ the inhibition was 95. $1 \%$.

The results in terms of persistently infected cells are shown in Figure 3. FRhK-4 cells persistently infected with hepatitis A virus were less responsive to treatment with ribavirin than acutely infected cells. Treatment with 25, 50 and $100 \mu \mathrm{g} / \mathrm{mL}$ ribavirin reduced the hepatitis A virus antigen yield by 34, 60 and $82 \%$, respectively. When the ribavirin-treated cells were passaged and re-treated with the same dose of drug, the inhibitory effect was more pronounced but not statistically significant.

\section{DISCUSSION}

Hepatitis A virus, though considered a picornavirus, has proven to be resistant to inhibition by guanidine and 2-(alpha-hydroxybenzyl)-benzimidazole (7). Among other antivirals tested so far for antihepatitis A virus activity, ribavirin seems promising $(2,4)$, more so because it has been well characterized clinically $(3,8)$.

The data presented here indicate that ribavirin at a dosage of $50 \mu \mathrm{g} / \mathrm{mL}$ significantly reduced the yield of hepatitis A virus antigen in acutely infected cells, and when $100 \mu \mathrm{g} / \mathrm{mL}$ was used no residual antigen could be detected in infected cells, even when the dose of hepatitis A virus was increased from 100 to 800 TCID50. These results do not rule out the presence of a very small amount of infectious virus which could not be detected by radioimmunoassay. The radioimmunoassay detects hepatitis A virus protein antigen, not infectious virus. The effect of ribavirin at a dosage of $100 \mu \mathrm{g} / \mathrm{mL}$ was not likely due to cytoxicity, as most of

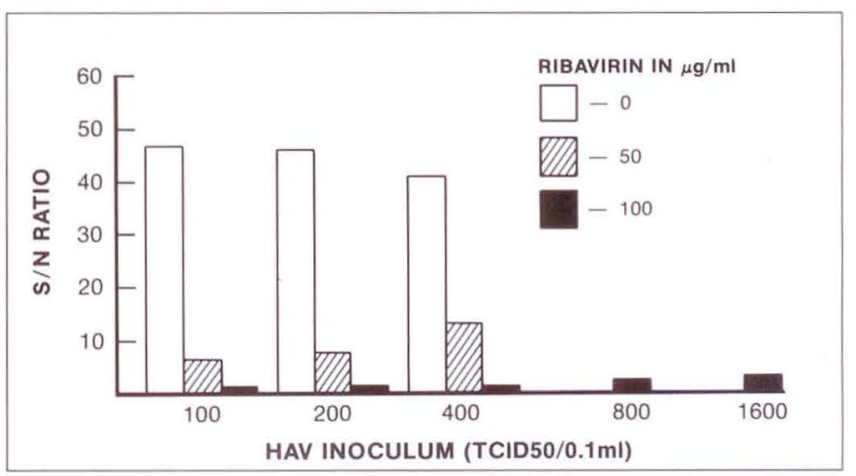

Figure 2) Effect of ribavirin on hepatitis A virus (HAV) replication in fetal Rhesus monkey kidney cells (FRhK-4). The $S / N$ value indicates the ratio of sample counts per minute to negative control by radioimmunoassay. TCID 50 Tissue culture infectious dose 50

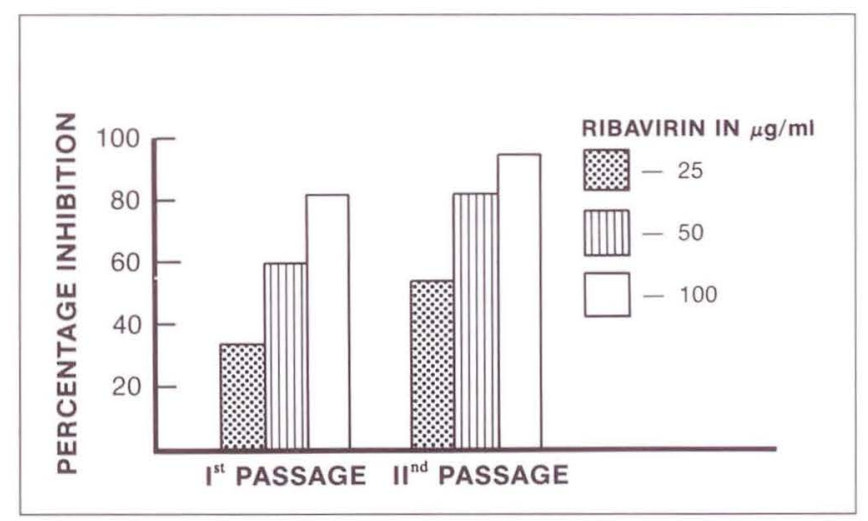

Figure 3) Effect of ribavirin on fetal Rhesus monkey kidney cells (FRhK-4) persistently infected with hepatitis A virus. Cells were treated either during the first passage or during both first and second passages. The percentage inhibition was calculated ( $\mathrm{S} / \mathrm{N}$ ratio of untreated HAV $S / N$ ratio of treated $H A V \times 100) \div S / N$ ratio of untreated $H A V$, where $S / N$ ratio is the ratio of sample to negative control mean hepatitis A virus antigen harvested from treated or untreated infected cell cultures

the cells were viable and the inhibition of cell growth was not sufficient to produce this effect.

Hepatitis A virus antigen production was also inhibited by ribavirin in persistently infected cells. The expression of hepatitis A virus antigen was significantly reduced $(82 \%)$ at a ribivarin dosage of $100 \mu \mathrm{g} / \mathrm{mL}$. The anti-hepatitis A virus effect of ribavirin on persistently infected cells has, to the authors' knowledge, not been reported before. Ribavirin was less effective in persistently infected cells, which is similar to results obtained for the mumps virus (9). On the other hand, cells persistently infected with 'foot and mouth disease' virus were cured by ribavirin (10).

These findings indicate that ribavirin has an inhibitory effect on hepatitis A virus in vitro and should be further evaluated for therapeutic activity. 
ACKNOWLEDGEMENTS: We thank Dr K Rozee for reviewing the paper and Mrs M Kanabe for secretarial help. We also thank Mrs T Mo and Miss C Parker for excellent technical assistance. Anton $\mathrm{P}$ Andonov is a visiting Fellow from the Institute of Infectious and Parasitic Diseases in Sofia, Bulgaria.

\section{REFERENCES}

1. Ohara H, Ibisawa I, Ohtani S. Prophylactic efficacy of immune serum globulin against hepatitis A. Jpn J Exp Med 1986;56:223-33.

2. Widell A, Hansson BG, Dberg B, Nordenfelt E. Influence of twenty potentially antiviral substances on in vitro multiplication of hepatitis A virus. Antiviral Res 1986;6:103-12.

3. Hall CB, McBridge JT, Walsh EE, et al. Aerosolized ribavirin treatment of infants with respiratory syncytial viral infection. N Engl J Med 1983;308:1443-7.

4. Passagot J, Biziagos E, Czanee JM, Deloinee R. Inhibition of hepatitis A virus replication in vitro by antiviral substances. J Med Virol 1987;24:24A. (Abst)
5. Lennet H, Schmidt NJ. Diagnostic procedures for viral rickettsial and chlamydial infections. In: Lennet $\mathrm{H}$, ed. Diagnostic Procedures for Viral Rickettsial and Chlamydial Infections. Washington: American Public Health Association Inc, 1973:34.

6. Chaudhary RK. Detection of hepatitis A virus by a modified commercial radioimmunoassay. Am J Clin Pathol 1984;81:337-8.

7. Siegl G, Eggers HJ. Failure of guanidine and 2-(alpha-hydroxybenzyl)-benzimidazole to inhibit replication of hepatitis A virus in vitro. J Gen Virol 1982;61:111-4.

8. Canonico PG. Efficacy, toxicology and clinical application of ribavirin against virulent RNA viral infections. Antiviral Res 1985;(Suppl 1):75-81.

9. McCammon JR, Rieser VW. Effects of ribavirin on BHK-21 cells acutely or persistently infected with mumps virus. Antimicrob Agents Chemother 1973;15:356-60.

10. Torre JC, Alareon B, Martinez-Salas E, Carrasco L, Domingo E. Ribavirin cures cells of a persistent infection of foot and mouth disease virus in vitro. J Virol 1987;61:233-5. 


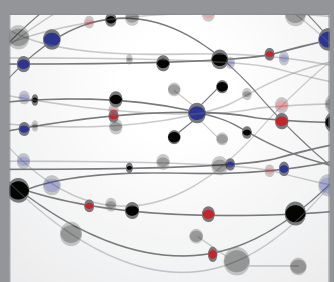

The Scientific World Journal
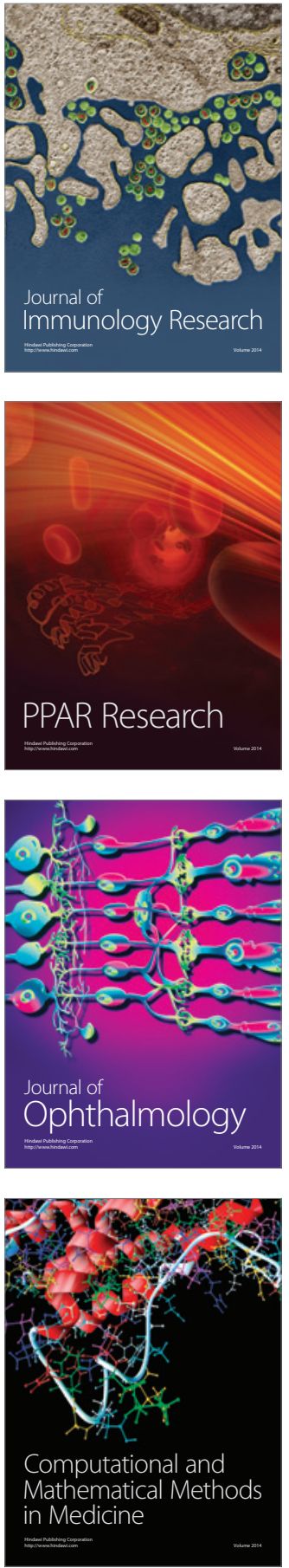

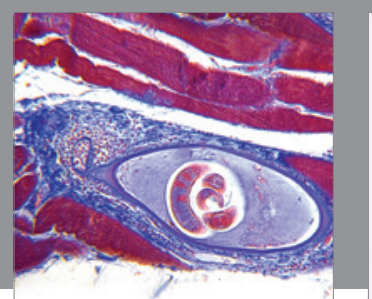

Gastroenterology Research and Practice

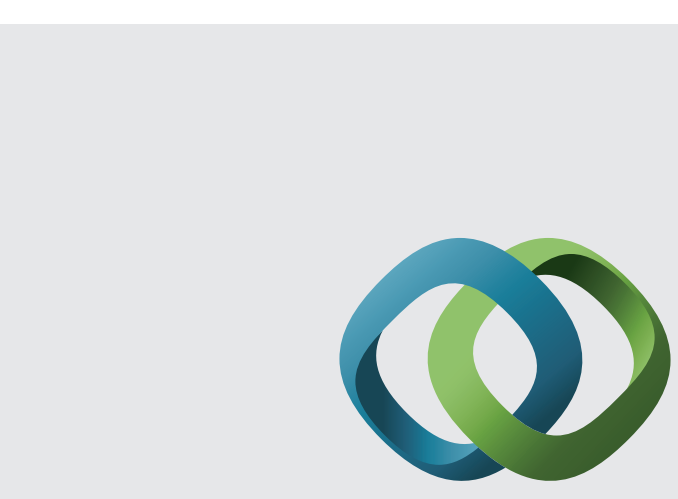

\section{Hindawi}

Submit your manuscripts at

http://www.hindawi.com
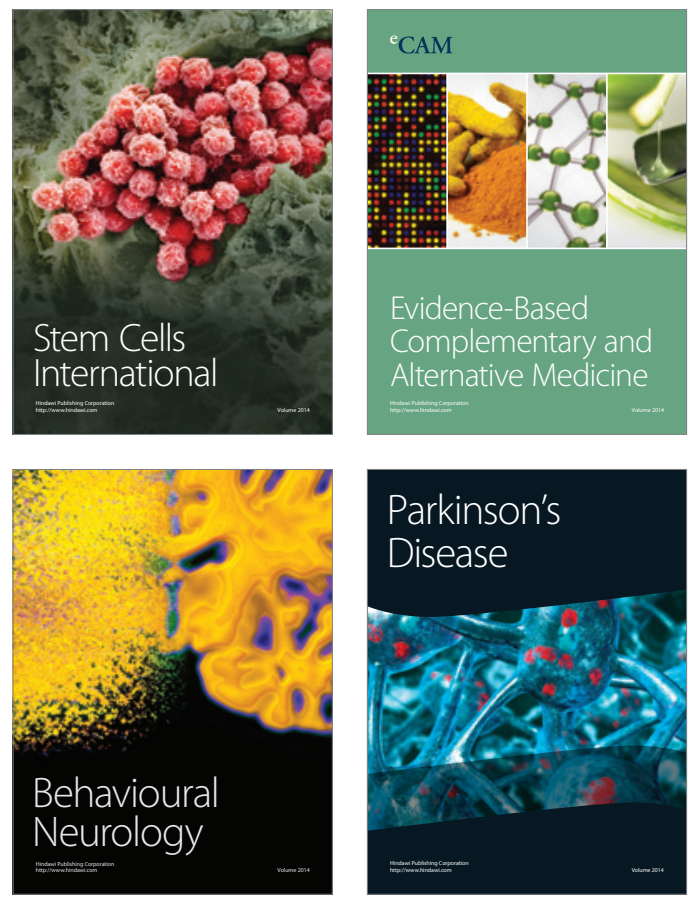
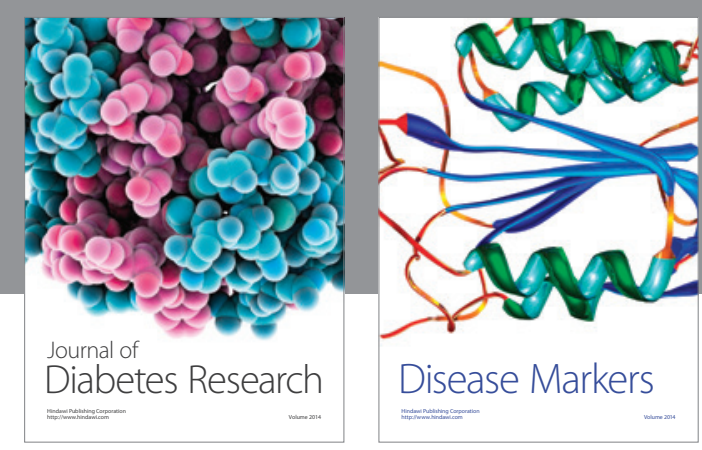

Disease Markers
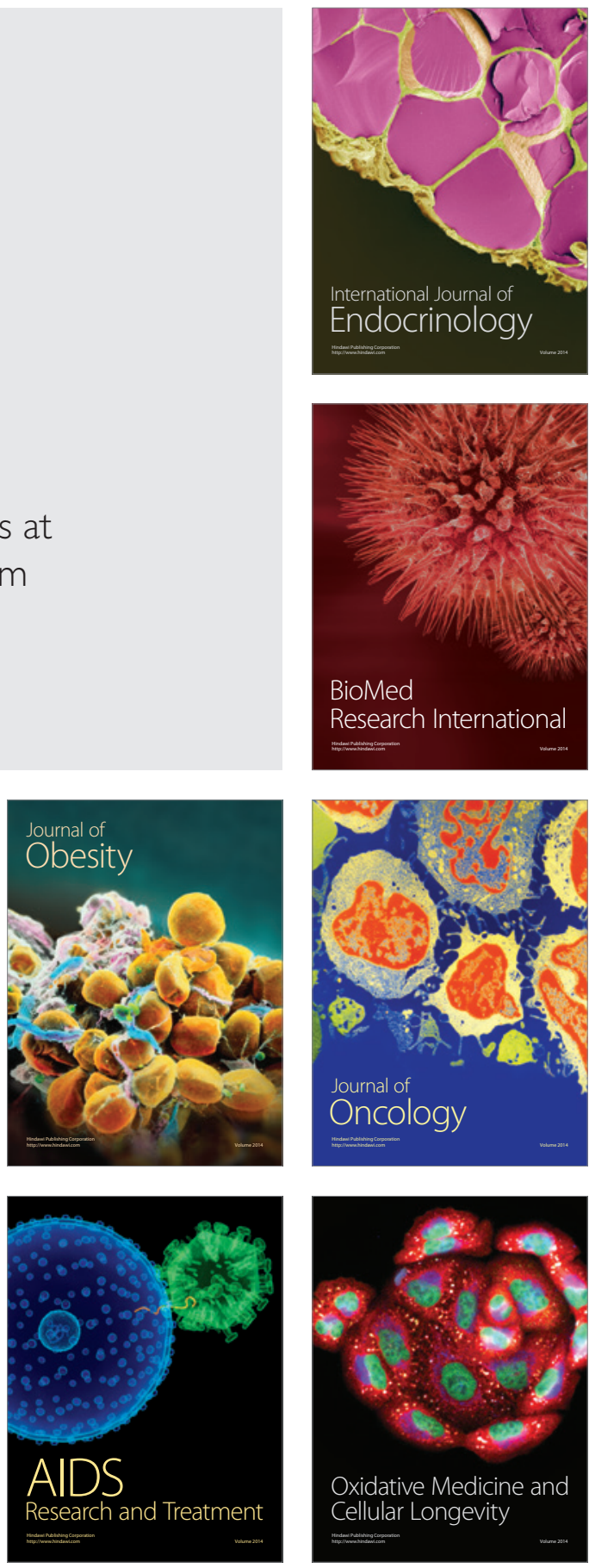